\title{
ON THE ISSUE OF ADMINISTRATIVE AND LEGAL REGULATORY MECHANISM IN THE DOMESTIC PHARMACEUTICAL INDUSTRY RELATIONS
}

\author{
O.V. GULAC, Dr. (Law), \\ associate professor of the Department of Administrative and Financial Law, \\ National University of Life and Environmental Sciences of Ukraine \\ E-mail: lenagulac8118@ukr.net
}

\begin{abstract}
Summary. The article analyzes the individual components of the mechanism of administrative and legal regulation of relations in the domestic pharmaceutical industry at the present stage. Some problematic aspects of such activity are outlined. The legal bases of regulation of relations in the domestic pharmaceutical industry and the preconditions for reforming both the industry as a whole and its institutional component are determined. It is noted that the state policy in the pharmaceutical sector is implemented by public authorities, however, which, based on the constant change of the central executive system and decentralization reform, undergo quite frequent transformations, which directly affects the quality of their direct functions. In the pharmaceutical industry of Ukraine, there are a number of problematic issues, including corruption. One of the most painful problems facing the country is the problem of providing the population with quality and affordable medicines. The directions of activity of the domestic pharmaceutical branch are analyzed. It is noted that the administrative and legal regulation of relations in the pharmaceutical industry is an integral part of national management. The mechanism of administrative and legal regulation of relations in the pharmaceutical industry is considered as a system of tools (legal, organizational and institutional), which are components of the impact of this branch of law on public relations in the pharmaceutical industry and aimed at ensuring its proper functioning. The analysis of elements of administrative and legal regulation of relations in the pharmaceutical industry is carried out.
\end{abstract}

Keywords: pharmaceutical industry, mechanism of administrative and legal regulation, administrative and legal regulation of relations in the pharmaceutical industry, health care legislation, medical industry, administration in the medical field

\section{Introduction.}

There are significant and rather rapid changes in all spheres of public life in Ukraine nowadays. The state has a significant influence on the regulation of relations in the pharmaceutical indus- try of Ukraine, which is extremely important for every resident of our country, as it is part of the health care sector as a whole. Such activities are especially relevant given the importance and significance of the pharmacological market, in the global dimension, which 
is designed to stop the rapid spread of the COVID epidemic.

Public policy in the pharmaceutical sector is implemented by public authorities, however, which, based on the constant changes in the system of central executive bodies and decentralization reforms, undergo frequent transformations, which directly affects the quality of their direct functions.

Nowadays, pharmacy in Ukraine is a multicomponent industry brings together numerous powerful centers of science, education, production and quality control of medicines, pharmaceutical market, pharmacy chains and wholesale warehouses, a wide field of information for specialized publications, as well as public associations and professional associations, and which, moreover, is directly related to health care (Together we are a force! Pharmacy, 2014).

\section{Analysis of recent researches and publications.}

Great number of scientists have devoted their researches to certain aspects of the mechanism of administrative and legal regulation of relations in the domestic pharmaceutical industry. In particular, Dutchak carried out research on the structure and function of state regulation of the development of the pharmaceutical market of Ukraine; Volk conducted an analysis of the executive authorities as subjects of administrative and legal regulation of the pharmaceutical industry; Gladun researched administrative and legal regulation in the field of health care under the legislation of Ukraine; Volk and Svitlychny conducted an indepth monograph on the study of the current state of administrative and legal regulation of pharmaceutical activities in Ukraine and ways to improve it (Volk \& Svitlychnyi, 2018).
The purpose is an analysis of individual components of the mechanism of administrative and legal regulation of relations in the domestic pharmaceutical industry at the present stage with the outline of problematic aspects of such activities.

\section{Results.}

In accordance with Article 3 of the Law of Ukraine «Fundamentals of the legislation of Ukraine on health care», health care is a system of measures carried out by public authorities and local governments, their officials, health care institutions, medical and pharmaceutical workers and citizens with in order to preserve and restore physiological and psychological functions, optimal performance and social activity of man at the maximum biologically possible individual life expectancy(Fundamentals of Ukrainian legislation on healthcare: The Law of Ukraine, 1992).

In the pharmaceutical industry of Ukraine, there are a number of problematic issues, including corruption. One of the most painful problems facing the country is the problem of providing the population with quality and affordable medicines. At the same time, these issues are constantly raised in the media and at the highest state level. Therefore, «it is impossible to solve these problematic issues without a balanced legal policy, the role of which is that it is based on a system of goals, conceptual ideas of a strategic nature for the organization of social relations» (Davydov, 2008: 54).

The basic law of our state at the highest level establishes standards of medical protection. Yes, Thus, Article 49 of the Constitution of Ukraine declares that everyone has the right to health care, medical assistance and medical insurance. Health care is provided by state funding of rele- 
vant socio-economic, health and health prevention programs. The state creates conditions for effective and accessible medical care for all citizens. Medical care is provided free of charge in state and municipal health care facilities; the existing network of such establishments cannot be reduced. The state promotes the development of medical institutions of all forms of ownership (Constitution of Ukraine: The Law of Ukraine, 1996).

The basic postulates of reforming the domestic pharmaceutical industry are enshrined in the "Concept of public health development of Ukraine» and provide for: the creation and production of new domestic drugs; providing health care facilities and the population with quality medicines and medical devices; increasing the efficiency of pharmacies; improving the material and technical base of the industry; significant increase and renewal of existing fixed assets of health care, in particular through the optimization of resource provision, capital construction, modernization and replacement of obsolete technical equipment.At the same time, the following needs to be improved: the procedure for state registration of medicines and quality control; mechanisms of state regulation of prices for medicines; providing state and municipal health care institutions with reference books on prescription and overthe-counter lists of medicines registered in Ukraine, ensuring their unconditional observance by doctors when prescribing medicines to patients, etc.(Decree of the President of Ukraine, 2000).

The pharmaceutical industry covers various areas of socially useful activities, which is associated with a wide range of economic, financial and business activities and requires mandatory organizational and legal influence of the state by authorized public administration entities.
The activity of the pharmaceutical market is impossible without regulation by the state. Thus, in particular, according to Dutchak, state regulation of the pharmaceutical market is an objective need that should be known and taken into account. "The role of the state in the economic life of society today is significantly increasing. This is manifested in the development of a system of regulations aimed at regulating the pharmaceutical market, business, customs regulations, banking, pricing of medicines, compliance with appropriate conditions of clinical, production, distribution practices, conditions of storage and circulation of medicines in the context increase of social protection of the population» (Dutchak, 2007: 107).

The «multifaceted» legal regulation of this industry is mediated by the branching of different in their direction of regulations, different sectoral affiliation, the leading role among which play the rules of administrative law. The implementation of executive power in the pharmaceutical industry takes place in the form of management activities and can be carried out by executive bodies, local governments and individual non-governmental institutions (Volk, 2017: 15). The various aspects of the legal regulation of relations in the field of pharmacology are significantly influenced by specialized public organizations that exercise public control and follow any proposals for changes to the system of relevant legislation, minimizing corruption inherent in this industry more than any other.

Legal regulation covers various aspects of public life, and legal form acquire the basic and most important types of social relations in various spheres of human activity, which require not just a legislative form, but its substantive legal content. Thus, special legal knowledge of the fea- 
tures and manifestations of law, legal regulation and provision, achieved by jurisprudence, allow a better understanding of those social processes that are subject to legal influence by the state and require their legal regulation while filling its legal content (Yarmaki, 2006: 32). Administrative and legal regulation of relations in the pharmaceutical industry is an integral part of national management. After all, it is with the help of administrative law that the conditions are created for the activities of all subjects, both public and private, who perform the powers delegated by the state in the pharmaceutical industry. This fully applies to the objects of administrative and legal regulation of the domestic pharmaceutical industry.

Administrative and legal regulation of relations in the pharmaceutical industry, by analogy with other work Gulac, where it is proposed to consider in a broad and narrow sense, just in a broad sense it is proposed to consider as a mechanism of administrative and legal regulation of public relations in this area, its legal consolidation, protection, implementation and improvement (Gulac, 2020: 75). Based on the above, it is important to understand the category «mechanism of administrative and legal regulation», which, for example, Korzh-Ikaeva considers as a system of administrative and legal norms and interconnected entities that create full-fledged conditions for the implementation, protection, protection and restoration of citizens' rights (Korzh-Ikaieva, 2008: 8). In its turn, Iierusalimova considers such a system of means that are integral elements of the impact on public relations of this branch of law (Iierusalimova, 2006: 9). Khytra - a set of legal forms, tools and methods by which the influence is exerted on the subjects in order to ensure their full functioning (Khytra, 2011: 7; Gulac, 2020: 75).
We propose to consider the mechanism of administrative and legal regulation of relations in the pharmaceutical industry as a system of tools (legal, organizational and institutional), which are components of the impact of this branch of law on public relations in the pharmaceutical industry and aimed at ensuring its proper functioning (Gulac, 2020: 133).

During the period of Ukraine's independence, the regulatory framework for health care has been formed, which includes more than 5.5 thousand legislative and by-laws, which are comprehensive in nature, as they contain rules of many branches of law, including administrative, civil, criminal, financial, labor, social security, etc. The Ministry of Health of Ukraine with the participation of other central executive bodies in cooperation with the Verkhovna Rada and the Cabinet of Ministers of Ukraine has carried out significant work on the formation of regulatory framework in the field of health, in particular on the development and adoption of bylaws, of which more than 3.5 thousand - sanitary rules and regulations (Hladun, 2014: 106).

Norms of public law normatively define the purpose and tasks of these measures, consolidating the powers of the relevant public authorities, in particular medical, administration, by establishing hierarchical links and connecting the network of bodies, institutions and health care institutions into a single national health care system. At the same time, reforming health care in general is impossible without the use of administrative and legal means of regulation. In particular, Gladun sees as promising the study of methods of administrative and legal regulation of relations in this area, namely the combination of imperative and elements of dispositive methods and the formation on this basis of a 
universal method of administrative law, which combines features of both the first and second (Hladun, 2014: 107-109).

The elements of administrative and legal regulation of relations in the pharmaceutical industry, among others, include: state-defined system of public administration; the set of administrative and legal means established by the norms of law; public interest.One of the most important elements of the mechanism should be recognized as the principles by which it is formed, as the basis of the entire management process in general, including in the pharmaceutical industry. They are of the greatest importance for determining the general priorities, the strategy for the implementation of legal regulation, because the principles, given their abstract nature, effectively «operate» at the highest level (Hubriienko, 2006: 8).

Given the fundamental, basic nature of the principles of regulation of any sphere of public life, it is important to reflect them in sectoral legislation In particular, in contrast to the special Law of Ukraine «On Medicines» (On medicines: The Law of Ukraine, 1996), which regulates legal relations related to the creation, registration, production, quality control and sale of medicines and defines the rights and obligations of languages of enterprises, institutions, organizations and citizens, as well as the powers in this area of executive authorities and officials, more general normative legal act - the Law of Ukraine «Fundamentals of Legislation of Ukraine on Health Care» Article 4 defines health care as a priority principle of society and the state and one of the main factors of survival and development of the people of Ukraine, noting a list of principles directly affecting the pharmaceutical industry. The subjects of public administration in the pharmaceutical industry are the President of Ukraine, higher (Cabinet of Ministers of Ukraine), central (Ministry of Defense) of Health of Ukraine, the State Service of Ukraine for Medicines and Drug Control, the State Service of Ukraine for Food Safety and Cons umer Pro tection, the National Health Service of Ukraine) and local executive authorities (Department of Health of regional and state administrations), chief physicians of central district hospitals) and local governments (structural subdivisions of health care of city councils, heads of medical communal institutions) (Kolpakov et al., 2011: 240).

The system of subjects of legal relations in the field of administrative and legal regulation of the pharmaceutical industry is a complex entity, within which, in order to fulfill the tasks set by the state, a significant number of subjects of public and private law are united. Among the significant number of issues related to the activities of management entities in the pharmaceutical industry, the problematic issue is the management and coordination of public and private law in the field of medical certification. It is illogical to consider the period when the Ministry of Economic Development and Trade of Ukraine delegated to the subject of public law SE (state enterprise) «Ukrainian Medical Cer tific ation Center» and private law en titi es «Ukrainian Scientific Institute of Certification» and PE (private enterprise ) «POLITOX» powers in the field of certification of medicines. At the same time, the Ukrainian Medical Certification Center is subordinated to the Ministry of Health of Ukraine, while the Ukrainian Scientific Institute of Certification and the private enterprise POLITOX have in fact remained outside such functional subordination.

Legisla tive uncertainty of officials who have to draw up protocols on the main types of misdemeanors in the phar- 
maceuti cal industry (on administrative offenses for misdemeanors under the provisions of Articles 164, 167, 170, 188-9, $188-10,188)$ remains a problematic issue of a legal nature. In particular, protocols on administrative offenses must be drawn up by authorized officials of: the State Service of Ukraine for Medicinal Products and Drug Control (Articles 164, 167, $170,188-9,188-10)$ of the Code of Administ rative Offenses; State Service of Ukraine for Food Safety and Consumer Protection (for the production or sale of medic al devices, their storage, transportation, in violation of sanitary legislation, (Article 167 and Article 170), as well as in case of non-compliance with resolutions, order s, instructions, conclusions of officials of the State Service of Ukraine for Food Safety and Consumer Protection to eliminate violations of sanitary legislation, failure to provide them with the necessary information or false information, creating other obstacles to fulfill their obligations. languages (Articles 188-11) of the Code of Administrative Offenses.

The lack of state control over the price regulation of medicines means that the subject of control is the State Service of Ukraine for Food Safety and Consumer Protection, which is subordinated to the Minister of Economy, Trade and Agriculture of Ukraine, and not the State Service of Ukraine for Medicines and Drug Control, which has direct subordination to the Minister of Health of Ukraine (To the optimization of the system of central executive bodies: The Resolution of the Cabinet of Ministers of Ukraine, 2014).

This approach in terms of the mechanism of administrative and legal regulation of relations in the pharmaceutical industry indicates a lack of state control over drug prices. Given that the procedure for calculating marginal prices for medicines is approved by the Ministry of Health of Ukraine, we believe that the functions of price control for medicines and medical devices should be entrusted to the State Service of Ukraine for Medicines and Drug Control.

The diverse nature of the pharmaceutical industry determines the scope exercising public control over the pharmaceutical industry that provides grounds to clas sify public control exercised by the Ministry of Health of Ukraine, the State Service of Ukraine for Medicines and Drug Control, the State Service of Ukraine for Food Safety and Consumer Prot e ction and the National Health Service of Ukraine during: production; registration; storage; transportation; implementation; disposal and destruction; price regulation of medicines; attestation of pharmaceutical and medical workers.

At the same time, the public and relevant public organizations are an important factor in public quality control and the format $i$ on of pricing and other policies. In addition, the establishment of the State Medical Service of Ukraine raises discussions and concerns in the context of contradictions in the status and powers of this body, which do not comply with the laws of Ukraine «On Medicinal Products» and «On Basic Principles of State Supervision (Control) in Economic Activity» (On the basic principles of state supervision (control) in the sphere of economic activity: The Law of Ukraine, 2007). Considering this issue comprehensively, as well as taking in to account some limitations in the powers of this body, it is possible to predict the possibility of its further reorganization or liquidation.

\section{Conclusions and prospects.}

The art icle analyzes the individual components of the mechanism of administrative and legal regulation of relations

130 | ISSN 2663-1350 «ПРАВО. ЛЮДИНА. ДОВКІЛЛЯ»| «LAW. HUMAN. ENVIRONMENT» Vol. 12, № 1, 2021 
in the domestic pharmaceutical industry at the present stage. Some problematic aspects of such activity are outlined. The legal bases of regulation of relations in the domestic pharmaceutical industry and the preconditions for reforming both the industry a s a whole and its institutional component are determined. It is noted that the state policy in the pharmaceutical sector is implemented by public authorities, however, which, based on the constant change of the central executive system and decentralization reform, undergo quite frequent transformations, which directly affects the quality of their direct functions. The directions of activity of the domestic pharmaceutical industry are analyzed. It is noted that the administrative and legal regulation of relations in the pharmaceutical industry is an integral part of national management. The mechanism of administrative and legal regulation of relations in the pharmaceutical industry is considered as a system of tools (legal, organizational and institutional), which are components of the impact of this branch of law on public relations in the pharmaceutical industry and aimed at ensuring its proper functioning. The analysis of elements of a dministrative and legal regulation of relations in the pharmaceutical industry is carried out.

\section{References}

1. Davydov, P.A. (2008). Sootnoshenye subektov pravovoi polytyky y subektov prava. Pravovaia polytyky y pravazhyzn [Correlation of subjects of legal policy and subjects of law. Legal policy and law life], 1: 51-55 (in Russian).

2. D utchak, I.B. (2007). Struktura ta funktsii derzhavnoho rehuliuvannia rozvytku farmatsevtychnoho rynku Ukrainy. Naukovi zapysky [Structure and functions of state regulation of $d$ evelopmentpharmaceutical market of Ukraine], 2 (12): 106-112 (in Ukrainian).
3. G ulac, O.V. (2020). Teoretyko-metodolohich ni zasady administratyvno-pravovoho $z$ abezpechennia pozhezhnoi bezpeky v li sakh Ukrainy: Dysertatsiia ... d.iu.n.: 12.00 .07 «Administratyvne pravo i protses; finansove pravo; informatsiine pravo". Kyiv: NUBiP Ukrainy [Theoretical and methodological principles of administrative and legal support of fire safety in the forests of $U$ kraine: Dissertation: Doctor of Law: 12.00.07 «Administrative law and process; fina nce law; information law». NULES of Ukraine, Kyiv], 586 (in Ukrainian).

4. Hladun, Z.S. (2014). Administratyvno-pravove rehuliuvannia u sferi okhorony zdo rovia za zakonodavstvom Ukrainy. Vis nyk Natsionalnoi akademii pravovykh nau k Ukrainy [Administrative and legal reg ulation in the field of securityhealth under the legislation of Ukraine. Bulletin of the National Academy of Legal Sciences of Ukraine], 1 (76): 103-111 (in Ukrainian).

5. Hubriienko, O.M. (2006). Orhanizatsiino- pravovi zasady derzhavnoho upravlinnia $v$ haluzi elektroenerhetyky $v$ Ukraini: avt oref. dys. kand. yuryd. nauk: 12.00.07. Irpin, [Organizational and legal principles of public administration in the field of electricity in Ukraine: author's ref. dis. Cand. jurid. Science: 12.00.07. Irpen], 20 (in Ukrainian).

6. lierusalimova, I.O. (2006). Mekhanizm adm inistratyvno-pravovoho zabezpechenn ia prav i svobod liudyny ta hromadianyna: avtoref. dys. ... kand. yuryd. nauk: 12.00.07. Kyiv [The mechanism of administrative and legal support of human and civil rights and freedoms: author's ref. dis. ... Cand. jurid. Science], 17 (in Ukrainian).

7. Khytra, I.Ya. (2011). Administratyvno-pravove zab ezpechennia diialnosti bankiv $v$ Ukraini: avtoref. dys. ... kand. yuryd. nauk: 12.00.07. Kyi v. [Administrative and legal support of ban ks in Ukraine: author's ref. dis. ... Cand. jurid. Science], 17 (in Ukrainian).

8. Kolpakov, V.K., Kuzmenko, O.V., Pastukh, I.D. \& Sushchenko, V.D. (2011). Adminis- 
tratyvne pravo Ukrainy. Zahalna chastyna: kurs lektsii. za red. V.V., Kovalenka [Administ rative law of Ukraine. General part: a course of lectures, ed. V.V. Kovalenko], 327 (in Ukrainian).

9. Konstytutsiia Ukrainy (1996): Zakon Ukr ainy [Constitution of Ukraine: The Law of Ukraine] 28.06.1996 № 254. Availabl e at: https://zakon.rada.gov.ua/laws/ sho $w / 254 \% D 0 \% B A / 96-\% D 0 \% B 2 \% D 1 \% 80$ \#Text (in Ukrainian).

10. Kontseptsiia rozvytku okhorony zdorovia naselennia Ukrainy (2000): Ukaz Prezydenta Ukrainy [The concept of health care development in Ukraine: Decree of the Preside nt of Ukraine] 07.12.2000. № 1313. Ava ilable at: http://zakon5.rada.gov.ua/ laws/show/1313/2000 (in Ukrainian).

11. Korzh-Ikaieva, T.H. (2008). Administratyvno- pravove zabezpechennia prav I svobod nepovnolitnikh: avtoref. dys. ... kand. yuryd. nauk: 12.00.07. Kyiv. [Administrative and legal support of the rights and freedoms of minors: author's ref. dis. ... Cand. jurid. Science], 17 (in Ukrainian).

12. Osnovy zakonodavstva Ukrainy pro okhoronu zdorovia (1992): Zakon Ukrainy [Fundamentals of Ukrainian legislation on health care: The Law of Ukraine] 19.11.1992. № 2801. Available at: https://zakon.rada.gov. ua/laws/show/2801-12 (in Ukrainian).

13. Pro likarski zasoby (1996): Zakon Ukrainy [A bout medicines: The Law of Ukraine] 04.04.1996. № 123. Available at: https:// za kon.rada.gov.ua/laws/show/123/96\%D0\%B2\%D1\%80 (in Ukrainian).

14. Pro optymizatsiiu systemy tsentralnykh orhaniv vykonavchoi vlady (2014): Postano va Kabinetu Ministriv Ukrainy [To the optimization of the system of central ex- ecutive bodies: The Resolution of the Cabin et of Ministers of Ukraine] 10.09.2014. № 442. Available at: https://zakon.rada. go v.ua/laws/show/442-2014-\%D0\%BF\#Text (in Ukrainian).

15. Pro osnovni zasady derzhavnoho nahliadu (kontroliu) u sferi hospodarskoi diialnosti (2007): Zakon Ukrainy [On the basic principles of state supervision (control) in the sp here of economic activity: The Law of Ukraine] 05.04.2007. № 877. Available at: https://zakon.rada.gov.ua/laws/show/87716 (in Ukrainian).

16. Vmeste mi - sila! (2014). Apteka [Together we are a force! Pharmacy],40 (961). Available at: http://www.apteka.ua/article/417991 (in Russian).

17. Volk, N.V. (2017). Orhany vykonavchoi vlady yak subiekty administratyvno-pravovoho rehuliuvannia farmatsevtychnoi haluzi. Naukovyi visnyk Uzhhorodskoho natsionalnoho universytetu. Seriia «Pravo» [Executive bodies as subjects of administrative and legal regulation of the pharmaceutical industry. Scientific Bulletin of Uzhhorod National University. Law Series], 44. P. 2: 15-19 (in Ukrainian).

18. Volk, N.V. \& Svitlychnyi, O.P. (2018). Administratyvno-pravove rehuliuvannia farmatsevtychnoi diialnosti v Ukraini: shliakhy vdoskonalennia: monohraf. Kyiv: NUBiP Ukrainy [Administrative and legal regulation of pharmaceutical activity in Ukraine: ways to improve: monograph], 185 (in Ukrainian).

19. Yarmaki, H.P. (2006). Administratyvno-nahliadova diialnistmilitsii v Ukraini: monohrafiia. Odesa. yuryd. lit. [Administrative and supervisory activities of the police in Ukraine: monograph. Odessa], 366 (in Ukrainian).

\section{О.В. ГУЛवК (2021). ДО ПИТАННЯ ПРО МЕХАНІЗМ АДМІНІСТРАТИВНО-ПРАВОВОГО РЕГУЛЮВАННЯ ВІДНОСИН У ВІТЧИЗНЯНІЙ ФАРМАЦЕВТИЧНІЙ ГАЛУЗІ. ПраВО.} Людина. Довкілля, 12(1): 125-133. https://doi.org/10.31548/law2021.01.014. 
Анотація. В статті здійснено аналіз окремих складових механізму адміністративноправового регулювання відносин у вітчизняній фармацевтичній галузі на сучасному етапі. Окреслено окремі проблемні аспекти такої діяльності. Означено правові основи регулювання відносин у вітчизняній фармацевтичній галузі та передумови реформування як галузі у цілому, так і ї̈ інституційної складової. Зауважено, що державну політику у фармацевтичній галузі реалізовують органи державної влади, щоправда, які, виходячи з постійної зміни системи чентральних органів виконавчої влади та реформи децентралізації, зазнають доволі частих трансформацій, що прямо впливає на якість виконання ними своїх безпосередніх функцій. Проаналізовано напрями діяльності вітчизняної фармацевтичної галузі. зазначено, що адміністративно-правове регулювання відносин у фармацевтичній галузі є складовою частиною загальнодержавної управлінської діяльності. Механізм адміністративно-правового регулювання відносин у фармацевтичній галузі розглянуто як систему засобів (правового, організаційного та інституційного характеру), які є складовими елементами впливу цієї галузі права на суспільні відносини у фармацевтичній галузі та спрямовані на забезпечення належного рівня ї̈ функціонування. Здійснено аналіз елементів адміністративно-правового регулювання відносин у фармацевтичної галузі.

Ключові слова: фармачевтична галузь, механізм адміністративно-правового регулювання, адміністративно-правове регулювання відносин у фармацевтичній галузі, законодавство про охорону здоров'я 